\title{
PEREMPUAN BERWIRAUSAHA: INOVASI, PENGAKUAN KEMAMPUAN PELUANG DAN ORIENTASI PASAR TERHADAP KINERJA PEMASARAN UMKM DI DKI JAKARTA
}

\author{
(WOMEN ENTREPRENEURIAL: INNOVATION, RECOGNITION OF \\ OPPORTUNITY AND MARKET ORIENTATION TO THE MARKETING \\ PERFORMANCE OF DKI JAKARTA'S MSMES)
}

\author{
Oleh: \\ Siti Mahmudah ${ }^{1)}$; Muhamad Asari ${ }^{2)}$ \\ Sekolah Tinggi Ilmu Ekonomi IPWI Jakarta1,2) \\ idajpram@yahoo.com ${ }^{1)}$; rafi1504@yahoo.com ${ }^{2}$
}

Submit: 11 Jul 2019

Review: 03 \& 15 Aug 2019

Accept: 15 Aug 2019

\begin{abstract}
The purpose of this study was to determine the influence of existing variables, namely Innovation, Recognition of Opportunity Ability and Market Orientation on Marketing Performance of DKI Jakarta's MSMEs. The study population was women entrepreneurs in DKI Jakarta. The research sample of 200 female entrepreneurs. The study uses a quantitative approach with multiple linear regression analysis. The results of the study prove that Innovation, Recognition of Opportunity Capabilities and Market Orientation affect Marketing Performance.
\end{abstract}

Keywords:

Entrepreneurial Women, Innovation, Recognition of Opportunity Ability, Market Orientation, Marketing Performance

\begin{abstract}
ABSTRAK
Tujuan penelitian ini untuk mengetahui pengaruh antar variabel yang ada yaitu Inovasi, Pengakuan Kemampuan Peluang dan Orientasi Pasar dalam mempengaruhi Kinerja Pemasaran di UMKM DKI Jakarta. Populasi penelitian adalah wirausaha perempuan di DKI Jakarta. Sample penelitian sebanyak 200 orang. Penelitian menggunakan pendekatan kuantitatif dengan analisis regresi linier ganda. Hasil penelitian menunjukkan Inovasi, Pengakuan Kemampuan Peluang dan Orientasi Pasar berpengaruh terhadap Kinerja Pemasaran.
\end{abstract}

Kata kunci:

Perempuan Berwirausaha, Inovasi, Pengakuan Kemampuan Peluang, Orientasi Pasar, Kinerja Pemasaran 


\section{PENDAHULUAN}

Membangun Negara yang memiliki peluang besar di kancah Internasional tidaklah mudah. Tatanan Indonesia sebagai sebuah Negara maju memerlukan sebuah tahapan pembangunan di segala lini. Salah satunya adalah membangun kesejahteraan di bidang ekonomi. Upaya menuju kesejahteraan tersebut dapat diwujudkan dengan meningkatkan kualitas dan kuantitas kewirausahaan. Kewirausahaan memberikan warna tersendiri dalam perkembangan perekonomian masyarakat terutama tumbuhkembangnya usaha kecil (Mahmudah, 2017). Kewirausahaan merupakan kekuatan yang luar biasa untuk tumbukembangnya perekonomian suatu negara. Peran kewirausahaan sebagai kunci pertumbuhan ekonomi terutama melalui pengusaha kecil yang berhasil mengeksploitasi peluang industri dan komersial dalam skala kecil tidak dapat di bantah dan telah lama diakui (Garga dan Bagga, 2009).

Bangunan kewirausahaan akan diwarnai aspek gender yang kuat. Perempuan memberikan kontribusi yang signifikan bagi keluarga dan negara, terutama di era ekonomi yang sulit saat ini. Hal ini menunjukkan bahwa perempuan memiliki kekuatan dalam membangun perekonomian keluarga dan bahkan negara. Untuk itu, perlu pengujian berbagai peran ekonomi dan kontribusi pengusaha perempuan terhadap pertumbuhan ekonomi. Kewirausahaan bukanlah hal asing bagi perempuan. Dalam diri perempuan sudah sangat lekat dengan dunia kewirausahaan. Beberapa tahun terakhir, jumlah wanita yang memasuki lapangan usaha menunjukkan peningkatan yang menggembirakan. Perusahaan yang dimiliki kaum perempuan juga tumbuh dari waktu ke waktu (Davidson \& Burke, 2004). Hal ini juga ditegaskan oleh Still and Timms (2000) yang menyatakan bahwa perempuan memainkan peran utama dalam pertumbuhan usaha kecil di Australia. Selain itu, Pemerintah Inggris memperkirakan bahwa hampir seperempat dan sepertiga perusahaan bisnis di negara itu dimiliki oleh wanita (Fielden, Davidson, Dawe \& Makin, 2003). Fakta jumlah pengusaha perempuan meningkat, terjadi dan menjadi fenomena dunia. Keberhasilan kaum perempuan di Kewirausahaan sudah mulai tumbuh di tingkat dunia (Alam, Jani \& Omar, 2011). Daily \& Dalton (2003) menegaskan bahwa wirausaha perempuan memberikan perspektif dan pengalaman unik. Gaya kerja dan komunikasi perempuan lebih partisipatif dan berorientasi pada proses dan mempertimbangkan pilihan yang lebih luas dari opsi dan praktik strategis yang tergantung pada usia dan tingkat pendidikan.

Instruksi Presiden RI No. 4 Tahun 1995, mendefinisikan: 'Kewirausahaan adalah semangat, sikap, perilaku dan kemampuan seseorang dalam menangani usaha dan atau kegiatan yang mengarah pada upaya mencari, menciptakan, menerapkan cara kerja, teknologi dan produk baru dengan meningkatkan efisiensi dalam rangka memberikan pelayanan yang lebih baik dan memperoleh keuntungan yang lebih besar".

Dalam penelitian ini membahas kewirausahaan di tataran UMKM dengan Inovasi, Pengakuan Kemampuan Peluang dan Orientasi Pemasaran pengaruhnya terhadap Kinerja Pemasaran.

\section{TUJUAN PENELITIAN}

Tujuan penelitian ini untuk mengetahui gambaran dan pengaruh antar variabel yang ada yaitu Inovasi, 
Pengakuan Kemampuan Peluang dan Orientasi Pasar pengaruhnya terhadap Kinerja Pemasaran di UMKM DKI Jakarta.

\section{TELAAH LITERATUR DAN PENGEMBANGAN HIPOTESIS Inovasi}

Inovasi merupakan pengembangan dan implementasi gagasan-gagasan baru yang diciptakan oleh seseorang dalam jangka waktu tertentu sehingga membentuk berbagai aktivitas transaksi di dalam tatanan organisasi tertentu. Wahyono (2002) memberikan masukan adanya dua konsep inovasi: 1) keinovasian dan 2) kapasitas untuk berinovasi. Inovasi merupakan gerakan dari ada menjadi lebih baik lagi dan dari tiada menjadi ada sehingga bentukan inovasi ini sangat berkorelasi dengan bangunan kewirausahaan.

Pengusaha berinovasi dan inovasi dianggap sebagai pendorong penting pertumbuhan ekonomi dalam perumusan teori pertumbuhan endogen (Abosede dan Onakoya, 2013). Schumpeter (1934) juga berpendapat untuk dimasukkannya fungsi kewirausahaan dalam perumusan teori modern perusahaan.

West (2000) menyatakan bahwa inovasi merupakan pengenalan dan aplikasi yang sengaja di bentuk dalam pekerjaan, tim kerja atau organisasi berupa ide, proses, produksi atau prosedur baru dalam pekerjaan, tim kerja atau organisasi, yang dirancang untuk menguntungkan pekerjaan, tim kerja atau organisasi. Inovasi merupakan perpaduan antara kreativitas dan inovasi. Tahap awal inovasi, proses kreativitas mendominasi dan kemudian akan didominasi oleh proses implementasi. Inovasi dalam kewirausahaan terbagi atas dua tipe inovasi dasar yang membentuk keuntungan bagi suatu usaha dengan cara yang berbeda yaitu inovasi produk dan inovasi proses (McDaniel, 2002:105).

\section{Pengakuan Kemampuan Peluang}

Kemampuan pengakuan peluang dicirikan oleh keyakinan bahwa pencapaian keadaan masa depan yang berbeda dari keadaan sekarang dimungkinkan oleh investasi sumber daya yang langka dengan harapan pengembalian di masa depan (Austin, Stevenson \& Wei-Skillen, 2006)

Kemampuan pengakuan peluang seseorang berwirausaha terhadap situasi di mana ia dapat menciptakan kerangka tujuan baru untuk mengkombinasikan sumber daya yang diyakininya akan menghasilkan keuntungan (Shane, 2003). Para ahli berpendapat bahwa pengakuan peluang wirausaha adalah proses penemuan peluang yang bertujuan (Kirzner, 1997). Oleh karena itu, penelitian dari perspektif psikologi telah berupaya untuk mengeksplorasi mengapa beberapa orang dapat mengenali peluang kewirausahaan, sementara yang lain dalam konteks perusahaan yang sama tidak memiliki kemampuan untuk memahami peluang. Mayoritas literatur pengenalan peluang kewirausahaan telah berfokus pada variabel psikologis, seperti ciri-ciri kepribadian, yang dapat memengaruhi individu dalam memanfaatkan peluang (De Carolis dan Saparito, 2006).

\section{Orientasi Pasar}

Menentukan orientasi pasar memerlukan pengetahuan tentang jenis pasar yang akan dimasuki termasuk karakteristiknya. Dengan diketahuinya jenis dan karakteristik pasa maka dapat diketahui arah yang jelas mengenai orientasi pasar dari produk yang dihasilkan. Orientasi pasar untuk produk industri kerajinan logam adalah pasar 
dalam negeri/domestik dan pasar ekspor atau luar negeri.

Orientasi pasar penting bagi kelangsungan perusahaan seiring dengan meningkatnya persaingan global dan perubahan dalam kebutuhan pelanggan. Hal ini memberikan kesadaran bahwa perusahaan harus selalu dekat dengan pasar/konsumen (Swastha dan Handoko, 2000). Hal ini harus disikapi oleh wirausahawan bahwa orientasi pasar sangat penting dan harus ditetapkan terlebih dahulu berdasarkan analisis. Narver dan Slater (dikutip Sensi, 2006) menyatakan bahwa orientasi pasar merupakan budaya bisnis dimana organisasi menciptakan perilaku untuk terus berkreasi dalam menciptakan nilai unggul bagi pelanggan dengan memusatkan diri pada kepentingan jangka panjang serta profitabilitas. Orientasi pasar terdiri dari tiga komponen perilaku: orientasi pelanggan, orientasi pesaing dan koordinasi interfungsional.

\section{Kinerja Pemasaran}

Kinerja pemasaran merupakan salah satu faktor yang sering digunakan untuk mengukur dampak strategi perusahaan sebagai ukuran prestasi pasar dari produk yang dipasarkan, dimana setiap perusahaan berkepentingan mengetahui prestasi pasar produknya (Ferdinan, 2002). Pengukuran kinerja dengan kriteria tunggal tidak mampu memberi pemahaman komprehensif tentang kinerja perusahaan sesungguhnya (Prasetya, 2002). Meskipun kinerja pemasaran merupakan konstruk yang umum digunakan untuk mengukur dampak penerapan strategi perusahaan, namun, pengukuran kinerja menjadi permasalahan dan perdebatan klasik karena sebagai sebuah konstruk, kinerja pemasaran bersifat multidimensional karena memuat beragam tujuan dan tipe organisasi. Oleh karena itu akan lebih baik jika kinerja diukur menggunakan berbagai kriteria pengukuran sekaligus (multiple measurements). Pengukuran kinerja dengan kriteria tunggal (single measurement) tidak akan mampu memberikan pemahaman yang komprehensif tentang kinerja suatu perusahaan sesungguhnya. Dimensi Kinerja Pemasaran meliputi: pangsa pasar, kepuasan pelanggan, loyalitas/retensi pelanggan, ekuitas merek, inovasi, Efektivitas, Efisiensi dan Kemampuan Beradaptasi (Clark, 2001; dan Gao, 2010).

\section{Pengaruh Inovasi terhadap Kinerja Pemasaran}

Sismanto (2006) melakukan Analisis Pengaruh Orientasi Pembelajaran, Orientasi Pasar dan Inovasi terhadap Keunggulan Bersaing Untuk Meningkatkan Kinerja Pemasaran Industri Kecil dan Menengah Produk Makanan di Propinsi Bengkulu. Penelitian menghasilkan temuan bahwa: 1) orientasi pembelajaran berpengaruh positif terhadap inovasi produk, 2) orientasi pasar berpengaruh positif terhadap inovasi produk, 3) inovasi produk berpengaruh positif terhadap keunggulan bersaing, 4) keunggulan bersaing berpengaruh positif terhadap kinerja pemasaran.

Dewi (2006) dalam penelitiannya pada Industri Batik di Kota dan Kabupaten Pekalongan melakukan pendekatan Structural Equation Model. Hasil penelitian menunjukkan bahwa 1) orientasi pasar berpengaruh positif terhadap inovasi produk, 2) inovasi produk berpengaruh positif terhadap keunggulan bersaing, 3) keunggulan bersaing berpengaruh positif terhadap kinerja pemasaran. Inovasi teknis tidak berdampak pada kinerja organisasi secara langsung (Hongming et al., 2007). Namun Saunila (2014) menyatakan adanya 
hubungan antara inovasi dan kinerja perusahaan dengan arah positif.

H1: Inovasi berpengaruh positif dan signifikan terhadap Kinerja Pemasaran

\section{Pengaruh Pengakuan Kemampuan Peluang terhadap Kinerja Pemasaran}

Penelitian empiris telah memberikan bukti kuat bahwa pengetahuan dan pengalaman sebelumnya berhubungan positif dengan pengakuan peluang wirausaha (Ozgen, 2003; Shane, 2000; Ucbasaran et al., 2009). Baru-baru ini, para ahli berpendapat bahwa pengakuan peluang wirausaha adalah semacam proses pembelajaran yang memanfaatkan pengetahuan diam-diam seseorang (Dutta dan Crossan, 2005; Lumpkin dan Lichtenstein, 2005; Marvel dan Lumpkin, 2007). Pengakuan peluang wirausaha menekankan pada pengakuan dan eksploitasi individu atas ide dan peluang bisnis potensial, yang dapat dipandang sebagai strategi kewirausahaan individu dalam menemukan sumber daya untuk menghasilkan keluaran inovatif (Manev et al., 2005).

H2: Pengakuan Kemampuan Peluang berpengaruh positif dan signifikan terhadap Kinerja Pemasaran

\section{Pengaruh Orientasi Pasar terhadap Kinerja Pemasaran}

Ferdinand (2002) menyatakan semakin tinggi orientasi pasar, semakin tinggi pula kinerja pemasaran yang dicapai. Zhou et. al. (2009) menyatakan orientasi pelanggan berpengaruh dengan arah positif terhadap keunggulan inovasi dan diferensiasi pasar, tetapi orientasi pesaing tidak mempunyai efek terhadap keunggulan inovasi dan mempunyai pengaruh negatif terhadap keunggulan pasar. Kamya et. al. (2010) menyatakan adanya efek interaksi positif orientasi pasar dalam hubungan antara manajemen pengetahuan dan keunggulan bersaing. Sedangkan Afsharghasemi et al. (2013) menyatakan bahwa ada hubungan positif antara orietasi pasar terhadap keunggulan bersaing perusahaan manufaktur UKM di Malaysia.

H3: Orientasi Pasar berpengaruh positif dan signifikan terhadap Kinerja Pemasaran

Berdasarkan hipotesis tersebut maka dibuat gambar model di bawah ini:

Gambar 1

Model Penelitian

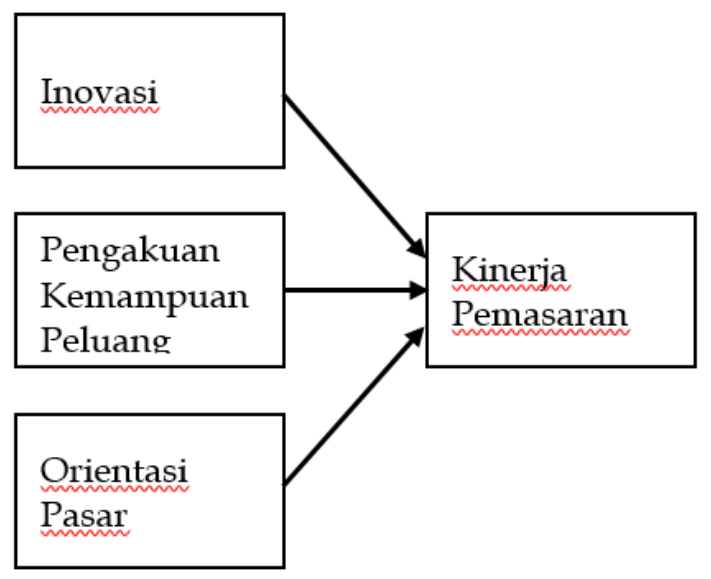

Sumber: Konsep Penelitian, 2019

\section{METODE PENELITIAN Sampel Penelitian}

Populasi penelitian ini adalah Perempuan Berwirausaha di DKI Jakarta. Sampel penelitian sebanyak 200 wirausaha perempuan. Teknik pengambilan sampel dengan teknik Insidental Sampling.

\section{Desain Penelitian}

Penelitian menggunakan empat variabel utama yaitu satu variable dependen Kinerja Pemasaran dan tiga variabel independen yaitu Inovasi, Pengakuan Kamampuang Peluang, dan Orientasi pasar.

\section{Operasionalisasi Variabel}

Operasionalisasi variabel penelitian dapat dikemukakan sebagai berikut: 
Tabel 1

Operasionalisasi Variabel

\begin{tabular}{|c|c|c|}
\hline Variabel & Indikator & Skala \\
\hline $\begin{array}{l}\text { Variabel X1 (Inovasi) } \\
\text { Sumber: Robbins, } 2010\end{array}$ & $\begin{array}{l}\text { - Struktur, } \\
\text { - Budaya, dan } \\
\text { - Praktik } \\
\text { sumber daya } \\
\text { manusia } \\
\text { organisasi itu } \\
\text { sendiri. }\end{array}$ & $\begin{array}{c}\text { Likert } \\
\text { dan } \\
\text { Ordinal }\end{array}$ \\
\hline $\begin{array}{l}\text { Yariabel X2 } \\
\text { (Pengakuan } \\
\text { Kemampuan Peluang) } \\
\text { Sumber: Ben Pam, } \\
2013\end{array}$ & $\begin{array}{l}\text { - Akuisi } \\
\text { Pengetahuan } \\
\text { - Persaingan } \\
\text { - Proaktif } \\
\text { - Tindakan } \\
\text { Kolektif }\end{array}$ & $\begin{array}{c}\text { Likert } \\
\text { dan } \\
\text { Ordinal }\end{array}$ \\
\hline $\begin{array}{l}\text { Uariabel X3 (Orientasi } \\
\text { Pasar) } \\
\text { Sumber: Never \& } \\
\text { Slater, 1990) }\end{array}$ & $\begin{array}{l}\text { - Orientasi } \\
\text { Pelanggan } \\
\text { - Orientasi } \\
\text { Pesaing } \\
\text { - Koordinasi } \\
\text { Antar } \\
\text { Fungsional }\end{array}$ & $\left|\begin{array}{c}\text { Likert } \\
\text { dan } \\
\text { Ordinal }\end{array}\right|$ \\
\hline $\begin{array}{l}\text { Yariabel Y (Kinerja } \\
\text { Pemasaran) } \\
\text { Sumber: Clark (2001) } \\
\text { dan Gao (2010) }\end{array}$ & $\begin{array}{l}\text { - Pangsa Pasar } \\
\text { - Kepuasan } \\
\text { Pelanggan } \\
\text { - Loyalitas } \\
\text { Pelanggan } \\
\text { - Ekuitas } \\
\text { Merek }\end{array}$ & $\mid \begin{array}{c}\text { Likert } \\
\text { dan } \\
\text { Ordinal }\end{array}$ \\
\hline
\end{tabular}

\section{Metode Analisis}

Metode analisis dalam penelitian ini menggunakan regresi dibantu dengan alat uji berupa SPSS (Statistical Package for Social Science). Analisis yang digunakan berturut-turut adalah penegujian kualitas data melalui validitas reliabilitas, uji asumsi lasik menggunakan normalitas homoskedastisitas, multikolinieritas; Uji model dan uji hipotesis.

\section{HASIL PENELITIAN DAN PEMBAHASAN \\ Pengujian Kualitas Data}

Pengujian Instrumen penelitian dilakukan dengan Uji Validitas dan Reliablitas. Sedangkan hasil pengujiannya yaitu: a. Uji Validitas dan Reliablitas Variabel $\mathrm{X} 1$

Berdasarkan hasil pengujian validitas dengan 8 butir pertanyaan variabel $\mathrm{X} 1$ yaitu hasilnya valid karena nilai rhitung > rProduct Moment $=0,138$ $(\mathrm{n}=200)$. Pengujian Reliabilitasnya dari 8 butir pertanyaan yaitu dengan nilai $\alpha$ hitung $(0,804)>$ aAnsoff $(0,6)$ maka hasilnya reliabel.

b. Uji Validitas dan Reliabilitas Variabel $\mathrm{X} 2$

Hasil pengujian validitas dengan 8 butir pertanyaan variabel X2 yaitu hasilnya valid karena nilai rhitung > rProduct Moment $=0,138 \quad(\mathrm{n}=200)$. Pengujian Reliabilitasnya dari 8 butir pertanyaan yaitu dengan nilai $\alpha$ hitung $(0,804)>\alpha$ Ansoff $(0,6)$ maka hasilnya reliabel.

c. Uji Validitas dan Reliablitas Variabel $\mathrm{X} 3$

Berdasarkan hasil pengujian validitas dengan 8 butir pertanyaan variabel $\mathrm{X} 1$ yaitu hasilnya valid karena nilai rhitung > rProduct Moment $=0,138$ $(\mathrm{n}=200)$ dan reliabel.

d. Berdasarkan hasil pengujian reliabilitas dengan 8 butir pertanyaan variabel $\mathrm{Y}$ yaitu hasilnya valid dan reliabel.

\section{Uji Asumsi Klasik Normalitas}

Berdasarkan pengujian normalitas bahwa variabel yang ada memiliki distribusi normal, hal ini dibuktikan dengan nilai Kolmogorov Smirnov (KS) dengan memiliki tingkat signifikansinya $>$ 0,05 . Selain itu berdasarkan histogram ada frekuensi yang dibangun sumbu $X$ dan $Y$ berbentuk merucut. 


\section{Uji Homoskedastisitas}

Deteksi ada tidaknya gejala heteroskedastisitas tersebut dilakukan dengan melihat ada tidaknya pola tertentu pada grafik scatterplots. Model regresi yang baik adalah yang homoskedastisitas atau tidak terjadi heteroskesdatisitas. Dalam penelitian ini hasilnya yaitu titiktitik menyebar secara acak serta tersebar baik di atas di bawah angka 0 pada sumbu Y. Hal ini dapat disimpulkan bahwa tidak terjadi heteroskedastisitas pada model regresi, sehingga model regresi layak digunakan untuk memprediksi variabel $Y$ (Kinerja Pemasaran) berdasarkan masukan variabel independen yaitu variabel $\mathrm{X} 1$ (Inovasi), variabel $\mathrm{X} 2 \quad$ (Pengakuan Kemampuan Peluang) dan variabel X3 (Orientasi Pasar).

\section{Hasil Uji Multikolinieritas}

Nilai Tolerance secara perhitungan nilai Toleransi (Tolerance) menunjukkan tidak ada variabel independen yang memiliki nilai Toleransi kurang dari 1, nilai Toleransi dan VIF masing-masing variabel yaitu: variabel X1 (Inovasi) nilai Tolerancenya yaitu 0,365 dengan nilai VIF yaitu 2,750, variabel X2 ( Pengakuan Kemampuan Peluang) nilai Tolerancenya yaitu 0,248 dengan nilai VIF yaitu 4,025 dan variabel X3 (Orientasi Pasar) nilai Tolerancenya yaitu 0,405 dengan nilai VIF yaitu 2,468

\section{Uji Model Pengaruh Inovasi, Pengakuan Kemampuan Peluang dan Orientasi Pasar terhadap Kinerja Pemasaran}

Pengaruh Inovasi, Pengakuan Kemampuan Peluang dan Orientasi Pasar terhadap Kinerja Pemasaran berdasarkan hasil pengujian hipotesis dengan uji $\mathrm{F}$ atau Uji Anova yaitu nilai F_hitung $=608,918$ dengan nilai sign 0,000 , sehingga hipotes nol (Ho) ditolak dan hipotes alternative (Ha) diterima, sehingga model memenuhi goodness of fit test sehingga layak digunakan untuk menjelaskan pengaruh Inovasi, Pengakuan Kemampuan Peluang dan Orientasi Pasar terhadap Kinerja Pemasaran, dengan R Adjusted Square sebesar 0,914 .

Nilai R sebesar 0,950 sedangan nilai Rsquare sebesar 0,903 yang artinya pengaruh Inovasi, Pengakuan Kemampuan Peluang dan Orientasi Pasar terhadap Kinerja Pemasaran sebesar 90,3\% sisanya sebesar 9,7\% yang dipengaruhi oleh variabel lain seperti Distribusi, Desain, Penetapan Harga dan lain-lain. Berdasarkan hasil persamaan regresinya yaitu $Y=0,189+0,560 X 1+0,338 \times 2+$ 0,176X3

\section{Uji Hipotesis}

\section{Pengaruh Inovasi terhadap Kinerja Pemasaran}

Berdasarkan hasil pengujian hipotesis bahwa thitungX1Y yaitu sebesar 14,880 dengan memiliki nilai sign 0,000 yang berarti hasilnya signifikan karena memiliki nilai sig. $<0,05$. Sedangkan nilai rata-rata variabel Inovasi (X1) 3,7425 dengan standar deviasi 0,64632. Pengaruh Inovasi terhadap Kinerja Pemasaran yaitu sebesar 0,560 dengan nilai rX1Y sebesar 0,907.

\section{Pengaruh Pengakuan Kemampuan Peluang terhadap Kinerja Pemasaran}

Berdasarkan hasil pengujian hipotesis bahwa thitungX2Y yaitu sebesar 7,203 dengan memiliki nilai sign 0,000 yang berarti hasilnya signifikan karena memiliki nilai sign $<0,05$. Nilai rata-rata variabel Pengakuan Kemampuan Peluangi (X2) 3,8085 dengan standar deviasi 0,62917. Pengaruh Pengakuan Kemampuan Peluang terhadap Kinerja Pemasaran yaitu sebesar 0,338 dengan nilai $\mathrm{rX2Y}$ sebesar 0,882 . 
Pengaruh Orientasi Pasar terhadap Kinerja Pemasaran

Berdasarkan hasil pengujian hipotesis bahwa thitungX3Y yaitu sebesar 4,650 dengan memiliki nilai sign 0,000 yang berarti hasilnya signifikan karena memiliki nilai sign $<0,05$. Nilai rata-rata variabel Orientasi Pasar (X3) 3,8640 dengan standar deviasi 0,60923. Pengaruh Orientasi Pasar terhadap Kinerja Pemasaran yaitu sebesar 0,176 dengan nilai $\mathrm{rX3Y}$ sebesar 0,758 .

\section{Pembahasan}

Model Pengaruh Inovasi, Pengakuan Kemampuan Peluang dan Orientasi Pasar terhadap Kinerja Pemasaran

Pengujian Model dengan Uji F atau Uji Anova yang berarti bahwa Pengaruh Inovasi, Pengakuan Kemampuan Peluang dan Orientasi Pasar terhadap Kinerja Pemasaran signifikan dengan nilai Uji Kebaikan dengan $\mathrm{R}$ Adjusted Square sebesar 0,914 nilai F_hitung $=608,918$ dengan nilai sig. 0,000 , sehingga hipotes nol (Ho) ditolak dan hipotes alternative (Ha) diterima, sehingga model memenuhi goodness of fit test sehingga model layak digunakan untuk menjelaskan pengaruh Inovasi, Pengakuan Kemampuan Peluang dan orientasi pasar. Hal ini sebagai penguatan bagi UMKM dalam membangun Kinerja Pemasarannya agar lebih baik memerlukan inovasi, mampu melihat peluang dan memiliki orientasi pasar.

\section{Pengaruh Inovasi terhadap Kinerja Pemasaran}

Pengaruh Inovasi terhadap Kinerja Pemasaran yaitu sebesar 0,560 dengan nilai rX1Y sebesar 0,907 dan nilai koefisien determinasinya sebesar 0,822 berarti pengaruh Inovasi terhadap Kinerja Pemasaran sebesar $82,2 \%$ yang sisanya sebesar 17,8\% dipengaruh di luar variabel Inovasi. Berarti pengaruhnya besar terhadap Kinerja Pemasaran. Hal ini memperkuat dengan hasil penelitian Saunilai (2014) dan Sismanto (2006). Hal ini berarti bahwa Inovasi harus terus ditingkatkan karena memiliki pengaruh yang kuat terhadap Kinerja Pemasaran. Apalagi dengan nilai persentase yang besar ini memberikan masukan bagi kita bahwa UMKM DKI Jakarta harus dapat meningkatkan inovasi produknya sehingga mampu kinerja meningkatkan pemasarannya.

\section{Pengaruh Pengakuan Kemampuan Peluang terhadap Kinerja Pemasaran}

Pengaruh Pengakuan Kemampuan Peluang terhadap Kinerja Pemasaran yaitu sebesar 0,338 dengan nilai rX2Y sebesar 0,882 dan nilai koefisen determinasinya sebesar 0,777 yang berarti bahwa pengaruh Pengakuan Kemampuan Peluang terhadap Kinerja Pemasaran sebesar $77,7 \%$ yang sisanya sebesar $22,3 \%$ dipengaruhi oleh variabel lain selain Pengakuan Kemampuan Peluang. Hal ini memperkuat hasil penelitian Shane (2003), Lumpkin (2007) dan Ucbasaran (2009). Hal ini berarti bahwa pengakuan kemampuan peluang terhadap Kinerja Pemasaran memiliki pengaruh yang rendah tetapi secara persentase memiliki pengaruh yang kuat sehingga para UMKM DKI Jakarta harus melihat peluang yang ada karena pengakuan kemampuan peluang merupakan hal yang penting dalam menjalankan suatu usaha.

\section{Pengaruh Orientasi Pasar terhadap Kinerja Pemasaran}

Pengaruh Orientasi Pasar terhadap Kinerja Pemasaran yaitu sebesar 0,176 dengan nilai rX3Y sebesar 0,758 dan nilai koefisien determinasinya sebesar 0,574 yang berarti pengaruh Orientasi Pasar terhadap Kinerja Pemasaran sebesar 57,4\% yang berarti sisanya dipengaruhi di luar 
variabel Orientasi Pasar. Hal ini memperkuat hasil penelitian Zhou (2009), Kamya (2010) dan Afsharghasemi (2013). Hasil penelitian ini menunjukkan bahwa Orientasi Pasar berpengaruh rendah sebesar 0,176 dan memiliki pengaruh secara persentase yang cukup sehingga hal ini memberikan masukan bagi UMKN DKI Jakarta bahwa Orientasi Pasar yang menjadi titik tolak pada usahanya harus diperkuat lagi sehingga Orientasi Pasar menjadi kekuatan dalam meningkatkan Kinerja Pemasaran.

\section{KESIMPULAN}

Simpulan dalam penelitian ini yaitu: Pengaruh Inovasi, Pengakuan Kemampuan Peluang dan Orientasi Pasar terhadap Kinerja Pemasaran siginifikan dan memiliki pengaruh yang kuat.

\section{SARAN}

a. Pemerintah harus mampu memberikan pembinaan pada UMKM dalam memperluas jaringan pasar sehingga orientasi pasar semakin meluas dan mendalam.

b. Penelitian berikutnya untuk lebih diperdalam dengan dimensi-dimensi variabel yang ada dengan metode analisis yang berbeda.

\section{DAFTAR PUSTAKA}

Ben Pam, W. (2013). Opportunity Recognition and Business Idea Generation as a Foundation for Entrepreneurial Businesses in Central Nigeria. International Journal of Business and Social Science, Vol. 4, No. 17, Special Issue-December)

Charles W. Lamb, Joseph F. Hair, Carl Mcdaniel, (2002). Pemasaran. Edisi Pertama, Salemba Empat, Jakarta
De Carolis, D. M., \& Saparito, P. (2006). Social capital, cognition, and entrepreneurial opportunities: A theoretical framework. Entrepreneurship Theory and Practice, 30(1), 41-56.

Lumpkin, G.T., \& Dess, G.G. (2001). Linking two dimensions of entrepreneurial orientation to firm performance: The moderating role of environment and industry life cycle. Journal of Business Venturing, 16(5), 429-451.

Mahmudah, Siti, (2017), Pendidikan Kewirausahaan, Lingkungan Keluarga dan Modal Sosial Pengaruhnya terhadap Minat Berwirausaha dan Dampaknya pada Kinerja Kewirausahaan Mahasiswa Yang Tergabung dalam Inkubator Kewirausahaan STIE IPWIJA, Prosiding Diskusi Panel Nasional Pendidikan Kewirausahaan LPPM Universitas Indraprasta PGRI, 29 Juli 2017 ISBN : 978-602-50181-0-7

Narver J.C.,Slater S.F. (1990). The effect of a market orientation on business profitability. The Journal of Marketing; 20-35.

Phan, P., Wright, M., Ucbasaran, D., \& Tan, W. L. (2009). Corporate entrepreneurship: Current research and future directions. Journal of Business Venturing, 24(3), 197-205. https://doi.org/10.1016/j.jbusvent.200 9.01.007

Sarwono, Sarlito Wirawan, (2012). Psikologi Remaja, PT. Raja Grafindo Persada, Jakarta.

Shane, S. (2003). A general theory of entrepreneurship: The individualopportunity nexus. UK: Edward Elgar.

Sismanto, A, 2006, Analisis Pengaruh Orientasi Pembelajaran, Orientasi Pasar dan Inovasi terhadap Keunggulan Bersaing untuk Meningkatkan Kinerja Pemasaran Fakultas Ekonomi Universitas.

Wahyono, (2002). "Orientasi Pasar dan Inovasi : Pengaruhnya Terhadap Kinerja Pemasaran" (Studi kasus pada Industri Meubel di Kabupaten 
Jepara). Jurnal Sains Pemasaran Indonesia, Vol I, No. I Program
Magister Manajemen. Universitas Diponegoro. 